\title{
Combination of High Dose Rate Radiations (10X FFF/2400 MU/min/10 MV X-rays) and Paclitaxel Selectively Eliminates Melanoma Cells
}

Short title: Concurrent treatments of radiation and paclitaxel kill melanoma cells

Authors: Niraj Lodhi ${ }^{1}$, Sreeja Sarojini ${ }^{1}$, Michaela Keck ${ }^{1}$, Poonam Nagpal ${ }^{1,2}$, Yuk Ming Chiu ${ }^{1}$, Zeenath Parvez $^{1}$, Laura Adrianzen ${ }^{1}$, K. Stephen Suh ${ }^{1}$

\section{Affiliations:}

1. The Genomics and Biomarkers Program, Hackensack University Medical Center, Hackensack Meridian Health, Hackensack, New Jersey, USA

2. College of Natural, Applied, and Health Sciences, Kean University, Union, NJ

\section{Corresponding Author:}

K. Stephen Suh, PhD

President

DiagnoCine,

Ex-Director, Genomics and Biomarkers Program

The John Theurer Cancer Center, Hackensack University Medical Center D. Jurist Research Building, 40 Prospect Avenue Hackensack, NJ 07601

E-mail: kstephensuh@gmail.com 


\begin{abstract}
:
Purpose: Melanoma is one of the most aggressive cancer with $1.6 \%$ of total cancer deaths in United States. In recent years treatment options for metastatic melanoma have been improved by the FDA approval of new therapeutic agents. However, these inhibitors based therapies are non-specific and have severe toxicities including hyperkeratosis, photosensitivity, hepatitis, arthralgia and fatigue. The aim of this study is to determine the synthetic lethal effect (paclitaxel and radiations) on melanoma cells and reduce the total radiation doses by increasing the dose rates up to $2400 \mathrm{MU} / \mathrm{min}$.
\end{abstract}

Methods: We previously reported a radiation treatment (10 MV x-rays, 10X-FFF, dose rate $2400 \mathrm{MU} / \mathrm{min}$, low total dose $0.5 \mathrm{~Gy}$ ) that kills melanoma cells with $80 \%$ survival of normal HEM in vitro. In this study we extended the radiation cycle up to four and include paclitaxel treatment to study the synthetic lethal effect on melanoma and two additional normal primary cells, HDF and HEK. Cells were treated with paclitaxel prior to radiations of dose rate of 400 and $2400 \mathrm{MU} / \mathrm{min}$ with total radiation dose of only $0.5 \mathrm{~Gy}$. To study induction of apoptosis and cell death, mitochondria respiration assay, DNA damage assay and colony formation assay were performed.

Results: Four days of consequent radiation treatment with paclitaxel significantly reduces the survival of melanoma cells by inducing of apoptosis and mitochondrial damages. After treatment, excessive DNA damage in melanoma cells leads to increase in expression of pro-apoptotic genes (Casp3) and decrease in expression of DNA repair gene (PARP1) and anti-apoptotic gene (Bcl2) to activate apoptosis pathway. Combination of paclitaxel and radiations reduces the survival of melanoma cells colonies when compared to radiation alone.

Conclusion: Our study indicates radiations with paclitaxel has potential synthetic lethal effect on melanoma cells and can be develop as therapy for melanoma without having toxicities or harmful effects to normal primary skin cells.

Keywords: Melanoma; Radiation therapy; Chemotherapy; Synthetic lethality; Apoptosis 


\section{Introduction:}

After identification of BRAF mutation, one of the important and major drivers of melanoma, it has led to the development of targeted therapies including immunotherapy, single agent or combination chemotherapy and radiotherapy [1]. However, the ten-year survival rate for metastatic melanoma continues to be $10 \%$, and the recent annual number of estimated newly diagnosed cases is greater than 73,000 with death numbers reaching almost 10,000 [2]. Melanoma was known to be a radio-resistant tumor initially [3] but as the radiotherapeutic measures evolved, it was proved that it is radio-sensitive and radiation therapy option is open [4]. Stereotactic body radiotherapy (SBRT) uses high dose rate of Flattening Filter Free (FFF) beams for cancer therapy because of the significantly shortened beam on time. A study of patients ( $n=84$ ) with multiple lesions (lung 75 , liver 10 , adrenal 6 , lymph nodes 5 , others 4) using 6 or 10 MV FFF beams demonstrated no acute toxicity on patients with overall survival (OS) at $94 \%$, indicating that radiotherapy can be used in melanoma treatment [5]. For unresectable malignant melanoma in the esophageal tract demonstrated that a chemo-radio combination is helpful in preventing supraclavicular metastasis with favorable palliative effects [6].

Paclitaxel (microtubules disassembly protector, blocks the progression of mitosis and triggers apoptosis) was introduced in cancer therapy decades ago and has been widely used for ovarian [7-10], breast [11, 12], Kaposi-Sarcoma (AIDS-related) [13-15] and lung carcinomas as a single agent or in combination with other drugs [16-20]. In multiple studies paclitaxel was investigated for its effectiveness to treat metastatic melanoma either as single agent or in combination with a small molecule inhibitor [21] small molecule inhibitors and carboplatin [22-24] or immunocytokine F8-IL2 [25]. For non-resection metastatic melanoma, paclitaxel is currently in clinical trial for first line therapy with other chemotherapy drugs with reporting of promising primary results [26]. Recent clinical practice uses chemo agents with radiotherapy for cancers. The paclitaxel and cisplatin combinations were used with Intensity-Modulated Radiation Therapy (IMRT) in a study in treating upper esophageal carcinoma with favorable results and no significant toxicities [27].

Here, we report the apoptotic effect on melanoma cells by combining the low dose paclitaxel with the high dose rate/low total dose (radiation) method. We treated both melanoma and normal primary skin cells Human Epidermal Melanocytes (HEM), Human Epidermal Keratinocytes (HEK) and Human Dermal Fibroblasts (HDF) for four consecutive days with a combination protocol to analyze the accumulative apoptotic effects on cancer cells in vitro. All melanoma cells were eliminated after four treatments and all normal primary skin cells were preserved and unharmed.

\section{Materials and methods:}

\subsection{Cell culture:}

Melanoma cell line WC00046 (V600E mutation in BRAF gene) (Figure 1A) purchased from Coriell Institute (Camden, NJ) was cultured in RPMI medium containing 10\% FBS, $1 \%$ penicillin/streptomycin (Invitrogen, Grand Island, NY). HEM and culture media were purchased (ScienCell, Carlsbad, CA), and HDF and HEK were prepared as previously described [28, 29].

\subsection{Radiation treatments to cells:}


Cells were seeded $(2 \times 105)$ in T-25 culture flasks (BD-Falcon), allowed to adhere overnight, and irradiated with $10 \mathrm{MV}$ x-rays at dose rates of $2400 \mathrm{MU} / \mathrm{min}$ or $400 \mathrm{MU} / \mathrm{min}$ by using TrueBeam (Varian Medical Systems, CA) with 10X-FFF mode. The radiation dose was administered to melanoma and normal cells as shown in Supplementary Figure 1 and Supplementary Table 1 . Where a duplicate set of cells of each group was pretreated with paclitaxel (50nM in DMSO; Sigma Aldrich,A) for two hours prior to each irradiating step $(\operatorname{Rad} \times 1, \operatorname{Rad} \times 2, \operatorname{Rad} x 3$, and $\operatorname{Rad} x 4)$. The cell culture medium was changed after two hours of each radiation. Cells were treated with paclitaxel only two hours prior to each irradiation. The titrated dose of 50nM paclitaxel was not toxic to normal skin cells for the entire duration of the experiment.

\subsection{Colony formation assays:}

One day after radiation, HEK, HEF, HEM, and melanoma cells were treated with trypsin, collected, and serially diluted (1:100, 1:1000, and 1:10000) for appropriate seeding in dishes (Corning, NY) with complete media. Colonized cells (typically 21 days) were stained with hematoxylin for $30 \mathrm{~min}$, fixed with $100 \%$ ethanol for $30 \mathrm{~min}$, washed in water and dried overnight for counting. Radiated cells were counted with a Beckman Coulter Counter (Brea, CA).

\subsection{RNA isolation and quantitative PCR:}

The TRIzol (Invitrogen, Grand Island, NY) method was used for RNA extraction, and selected genes were amplified by Q-RT-PCR with SYBR green (Qiagen, Valencia, CA) on the FAST Model 7900HT (Applied Biosystems, Carlsbad, CA). Data were analyzed using the SDS 7900HT software v2.2.2 application to determine the comparative threshold cycle $(\mathrm{Ct})$ method (2- $\Delta \Delta \mathrm{Ct}$ ) for calculating fold changes and standard deviations [30]. Primer sequences are given in Supplementary Table 2.

\subsection{Cell proliferation assay:}

The MTS assay (CellTiter $96^{\circledR}$ AQueous One Solution, Promega, Madison,WI) was used to assess cell proliferation of radiated cells by using a Microplate reader (BioTek Synergy HT) as described by the manufacturer and based on previous publication [28].

\subsection{Mitochondria respiration assay:}

Mitotracker Red CMXRos (Invitrogen-M7512) was used to stain cells at a final concentration of $200 \mathrm{nM}$ for analyzing mitochondria activity before and after radiation. After a 15-minute incubation at $37^{\circ} \mathrm{C}$ and $5 \% \mathrm{CO} 2$, cells were washed with PBS and fixed with 2\% PFA (paraformaldehyde) for 30 minutes at room temperature in the dark. Fixed cells were washed with PBS, mounted using DAPI, and fluorescent images were taken immediately with Zeiss Fluorescent microscopy (Axiovision). Cell fluorescence was quantified by using ImageJ.

\subsection{DNA damage assay:}

The EpiQuik In Situ Kit (Cat \# P-6001-096, Epigentek, Farmingdale NY) detected the phosphorylation of $\mathrm{H} 2 \mathrm{AX}$ at Serine 139 by a colorimetric method measured at 450nm in a 96-well plate where the cells are grown after radiation, fixed, and permeabilized according to the manufacturer's protocol. The DNA damage assay was carried out one hour after paclitaxel and the radiation treatment.

\subsection{Western blotting:}


Western blotting experiments were carried out by using cell lysates (Pierce IP lysis buffer cat\# 87788; Invitrogen) prepared from cell lines treated with or without Paclitaxel or radiation $\mathrm{x}$ 4. SDS-PAGE gels (12\%, Criterion TGX Precast Gels) were used to fractionate cell lysates and transferred onto a polyvinylidene difluoride (PVDF, Bio Rad) membrane using a Bio-Rad transfer unit (Hercules, CA). The membranes were blocked by using 5\% nonfat dry milk in TBST $(10 \mathrm{mmol} / \mathrm{l}$ Tris, $\mathrm{pH} 8.0,150 \mathrm{mmol} / \mathrm{l} \mathrm{NaCl}$, $0.5 \%$ Tween 20) for $60 \mathrm{~min}$; they were then washed and incubated with primary antibodies against $\mathrm{Bcl}-2$ (1: 1000, \#7973; Abcam, Cambridge, MA), caspase-3 (1:2000, H-277), PARP 1 (1:2000, \#SC-7148, SC8007; Santa Cruz Biotechnology Inc., Santa Cruz, CA) and Actin (1:10 000, AB-6276) at $4^{\circ} \mathrm{C}$ overnight. Actin was used as the loading control. The membranes were then washed and incubated with a 1:5000 dilution of horseradish peroxidase-conjugated donkey anti-mouse IgGs secondary antibody. The blots were washed and developed using the ECL system (Pierce). Doxorubicin (Dx, topoisomerase II inhibitor) treated cell lysates were used as a positive control $(+C)$ for Caspase 3 and negative control for PARP1 and $\mathrm{Bcl}-2$. Samples were used from a Rad $x 4$ experimental setting with (+Pac) or without (-Pac) Paclitaxel and with $(T)$ or without $(U)$ radiation treatment.

\subsection{Statistical analysis:}

All experiments were performed a minimum of three times, and data represent the results for assays performed in triplicate or quadruplicate. Error bars represent $95 \%$ confidence intervals (Cls). All statistics were based on continuous variables by using software STAT View, and P values $<0.05$ were considered statistically significant. For comparisons between two groups, the Student's t test was applied.

\section{Results:}

\subsection{Paclitaxel in combination with a high dose rate of $2400 \mathrm{MU} / \mathrm{min}$ (total dose $0.5 \mathrm{~Gy}$ ) significantly increases apoptosis in melanoma cells:}

Viable cells were counted four days after four consecutive days of the treatment (Figure 1A; Rad $x 1, x 2, x 3$, and $x 4)$. At the high dose rate $(2400 \mathrm{MU} / \mathrm{min}$ total dose $2 \mathrm{~Gy}$ Rad $\mathrm{x} 4$ ) in the presence of paclitaxel the normal skin cells tolerated the total dose of $2 \mathrm{~Gy}(0.5 \mathrm{~Gy} \times 4=2 \mathrm{~Gy})$ for both $400 \mathrm{MU} / \mathrm{min}$ and $2400 \mathrm{MU} / \mathrm{min}$ at the high dose rate, but the melanoma cells were selectively killed: $58 \%$ on day 1 (Rad $\mathrm{x} 1), 76 \%$ on day $2(\operatorname{Rad} \times 2), 96 \%$ on day $3(\operatorname{Rad} \times 3)$, and $98 \%$ on day $4(\operatorname{Rad} \times 4)$ (Figure $1 \mathrm{~A}, \mathrm{P}+$ $2400 \mathrm{MU} / \mathrm{min}, \mathrm{p}<0.005$ for all 4 treatments). The cell counts after the four consecutive treatments showed that melanoma cell survival percentages decreased 5-fold compared to the control (nonradiated, no paclitaxel) for $\mathrm{P}+400 \mathrm{MU} / \mathrm{min}$ and 50 -fold for $\mathrm{P}+2400 \mathrm{MU} / \mathrm{min}$, suggesting that $2400 \mathrm{MU} / \mathrm{min}$ in combination with paclitaxel is highly effective for killing melanoma cells while largely preserving normal skin cells (Figure 1A).

Based on bright field microscopy data, all normal skin cells HEM, HDF and HEK maintained above $85 \%$ cell survival after four consecutive daily radiations with or without paclitaxel and with $400 \mathrm{MU} / \mathrm{min}$ or $2400 \mathrm{MU} / \mathrm{min}$ dose rate (Figure $1 \mathrm{~B}$ ), suggesting that the titrated dose of paclitaxel and 0.5Gy of total dose delivery leads to minimal harm to normal skin cells. All skin cells retained proliferative potential and recovered fully three days after the fourth treatment. 


\subsection{Paclitaxel in combination with $2400 \mathrm{MU} / \mathrm{min}$ (total dose $0.5 \mathrm{~Gy}$ ) induces significantly higher DNA damage to melanoma cells:}

The treated cells were harvested two days after four consecutive treatments (Supplementary Table 1) and allowed to recover for at least 24 hours after each treatment prior to the subsequent radiation. Irradiating melanoma cells with $400 \mathrm{MU} / \mathrm{min}$ did not increase DNA damage, but the $2400 \mathrm{MU} / \mathrm{min}$ dose rate increased to three-fold more DNA damage than the control and $400 \mathrm{MU} / \mathrm{min}$ (Figure 2A). Normal skin cells showed moderate DNA damage in cells with radiation alone, but less than paclitaxel treated cases (Figure 2A), Despite DNA damage, cell proliferation markers CCND1 and CCND2 were moderately upregulated in treated normal skin cells, but downregulated in treated melanoma cells (Figure 2B). The level of radioprotection gene SOD2 was downregulated in melanoma cells while HEM upregulated the expression levels, suggesting that the DNA damage repair and radioprotection of normal skin cells are actively enhancing the survival of normal cells.

\subsection{Proliferation of melanoma cells reduce and mitochondrial respiration increase in paclitaxel and $2400 \mathrm{MU} / \mathrm{min}$ (total dose $0.5 \mathrm{~Gy}$ ) radiations treatment:}

MTT assay was used to investigate cell proliferation and mitochondrial respiration of normal skin cells and melanoma cells. The cell proliferation assay using MTS reagent suggested all normal skin cells HEM, HDF and HEK showed proliferation level close to or above the untreated control after four radiations, while proliferation was significantly reduced in melanoma cells after four radiations. Combination treatment is effective to reduce viability of melanoma cells $-44 \%(\operatorname{Rad} \times 1), 31 \%(\operatorname{Rad} \times 2)$, $4 \%(\operatorname{Rad} \times 3)$, and $0.5 \%(\operatorname{Rad} \times 4)$ versus viability of $>95 \%$ after four radiations with or without paclitaxel at dose rate of $2400 \mathrm{MU} / \mathrm{min}$ for normal skin cells (Figure $3 \mathrm{~A}$ ).

Dose rate $2400 \mathrm{MU} / \mathrm{min}$ caused higher mitochondrial respiration than $400 \mathrm{MU} / \mathrm{min}$ which was directly related to total dose of radiation delivered to cells. However, the respiratory chain gene (UCRC) was down regulated in melanoma cells, suggesting that the increased respiration activity after radiation was related to post-translational activation (Figure 3B).

\subsection{Expression of pro-apoptotic gene is elevated and DNA repair PARP1 gene and anti-apoptotic gene are down regulated in melanoma cells caused enhanced apoptosis:}

Anti-apoptotic $\mathrm{Bcl}-2$ was downregulated in irradiated and paclitaxel-treated melanoma cells on the RNA and protein level (Figure 4A). Pro-apoptotic Casp3 is upregulated in irradiated and paclitaxeltreated melanoma cells on the RNA level, but showed downregulation on the protein level (Figure 4B). However, normal skin cells retain expression of Casp3 and $\mathrm{Bcl}-2$ in treated and untreated cells (Figure $4 A, B$ ). DNA damage repair genes PARP1 (Figure 4C) was downregulated substantially in paclitaxel treated irradiated melanoma cells, while the expression levels were only slightly changed in normal skin cells. Protein analysis by anti-PARP1 showed the downregulation of levels in irradiated and paclitaxeltreated melanoma cells (Figure 4C), whereas untreated cells maintained base level expression.

A Mitotracker assay of melanoma cells treated with paclitaxel and irradiated at $2400 \mathrm{MU} / \mathrm{min}$ (Rad x4) showed no fluorescence, indicating cells undergoing apoptosis (Figure 5A and B). Minimal fluorescence was noticed in cells irradiated at $400 \mathrm{MU} / \mathrm{min}$ with paclitaxel even after four radiations, suggesting that paclitaxel induced more mitochondrial damage when co-administered with dose rate 
$2400 \mathrm{MU} / \mathrm{min}$ in cancer cells HEM, HDF and HEK showed no significant difference in fluorescence between $400 \mathrm{MU} / \mathrm{min}$ and $2400 \mathrm{MU} / \mathrm{min}$.

\subsection{Colony formation of melanoma cells diminished after four cycles of radiations at dose rate 2400MU/min (total dose $2 \mathrm{~Gy}$ ) and paclitaxel treatment:}

Colony formation assay has been used as the classic protocol in radiation research for determining the ability of a single cell to multiply into a colony [32]. Data showed that 2400MU has higher apoptotic potential on melanoma cells than $400 \mathrm{MU} / \mathrm{min}$ (Figure 6A). Co-administration of paclitaxel reduced the survival of colonies to $30 \%(\operatorname{Rad} \times 1), 18 \%(\operatorname{Rad} \times 2), 2 \%(\operatorname{Rad} \times 3)$, and $0 \%(\operatorname{Rad} \times 4)$ when compared to $2400 \mathrm{MU} / \mathrm{min}$ alone (Figure $6 \mathrm{~A}$ and $\mathrm{B}$ ). For normal skin cells, there was no significant difference between survival of colonies of irradiated and paclitaxel-treated cells when compared to radiation alone.

\section{Discussion:}

Melanoma is known to be radio-resistant, and radiotherapy is currently used for palliative, but not curative care. In recent years, many scientific efforts have been made to compromise DNA repair efficiency of melanoma cells, including radiation dose. The current study demonstrates the effectiveness of combining dose rate $2400 \mathrm{MU} / \mathrm{min}$ (at a low total dose of $0.5 \mathrm{~Gy}$ ) with paclitaxel, a cost-effective chemotherapeutic drug. Food and Drug Administration (FDA) approved paclitaxel induces DNA damage and mitochondrial disruptions along with microtubule inhibition [33]. We show that melanoma cell's survival is significantly reduced after four cycles of paclitaxel and radiation treatment at dose rate of $2400 \mathrm{MU} / \mathrm{min}$. while minimal affect in normal skin cells HEM, HDF and HEK (Figure 1). We measured DNA damage caused by radiations by phosphorylation of H2AXSer139 as was used by other research groups [34-41] in primary or melanoma cells. This assay shows that radiations at $2400 \mathrm{MU} / \mathrm{min}$ with paclitaxel induce prolonged DNA damage in melanoma cells and cause six-fold more DNA damage than $2400 \mathrm{MU} / \mathrm{min}$ alone (Figure $2 \mathrm{~A}$ ).

Excitation of mitochondria after exposure to ionizing radiation is related to upregulation of mitochondrial electron transport chain function which helps the cancer cells to become resistant to radiation [42]. Paclitaxel has the ability to damage the mitochondria by altering mitochondrial respiration and thus induce mitochondrial apoptosis [43]. We used MitoTracker probes, which passively diffuse across the plasma membrane and accumulate in active mitochondria in viable cells only [44-46]. Further, to confirm induction of DNA Damage Response (DDR) and pro or anti-apoptotic proteins to radiation exposure we performed western as in Figure 4, this combination upregulates AIF, BBC3, PARP1, and Casp3 genes in cancer cells to $>25$ fold. Cell cycle genes (CCND1/CCND2, Figure 2), DNA damage repair genes (PARP1, Figure 4), radioprotection genes (SOD2, Figure 2), and anti-apoptotic genes (Bcl2, Figure 4) were upregulated in normal skin cells while mitochondrial and extrinsic apoptotic pathway genes (AIF and BBC3) were upregulated in paclitaxel-treated, irradiated cells.

The colony formation assay assesses the cell reproductive death after radiation that is determined by the proportion of surviving colonies for each dose administered [47]. Our data show the decrease in cell survival for melanoma cells after paclitaxel treatment. Results were confirmed with the MTS assay, where a decrease in viability of melanoma cells was recorded when combined with paclitaxel, while normal cells retained their viability >95\% (Figure $3 A$ ). 
When melanoma cells are concurrently treated with paclitaxel, cell number and mitochondrial efficiency decrease and cells show low fluorescence for $400 \mathrm{MU} / \mathrm{min}$ and no fluorescence for $2400 \mathrm{MU} / \mathrm{min}$ after four radiations. This suggests that paclitaxel indues greater mitochondrial damage when co-administered with a dose rate of $2400 \mathrm{MU} / \mathrm{min}$ in melanoma cells. As shown in Figure $5 \mathrm{~A}$ and $\mathrm{B}$ viability of paclitaxel and radiation exposure cells is very low or none.

Co-administration of paclitaxel completely inhibited the survival of colonies in melanoma cells after four radiations at dose rate of $2400 \mathrm{MU} / \mathrm{min}$ (Figure 6). Similar to the standard radiotherapy (400MU/min), melanoma cells exhibit resistance to 400MU/Min in Rad x1 to Rad x4 (total dose 2Gy), even in the presence of paclitaxel; but our studies suggest that high dose rate radiation $(2400 \mathrm{MU} / \mathrm{min}$ of total dose 2Gy) completely abolishes the melanoma cells in combination with paclitaxel. In other studies paclitaxel was used with chemo and radiotherapy [31,48]. These studies are in clinical trials phase and their primary outcome measures are to improve the Overall Response Rate (ORR), Proliferation Free State (PFS) or Overall Survival (OS). Paclitaxel-based chemo-radiotherapy for non-small cell lung cancer (NSCLC) patients demonstrated that minimum toxicity and an optimal radio-chemo combination regimen are yet to be established with further studies [31]. Paclitaxel was also used in melanoma frontline therapy as single agent or in combination with carboplatin (DNA damaging agent) immunotherapeutic drugs (Ipilimumab) in a phase II clinical trial to find a new approach to increase survival rates of patients [48].

Our study is new approach for radiotherapy by increasing the dose rate and reduce the total dose $(0.5 \mathrm{~Gy})$ to lower toxic effects of radiations in combination of paclitaxel for treatment of BRAF mutant patients. In general patients get the 40-60 Gy of radiation dose in 4-5 cycles and that cause the severe side effects of other skin problems, fatigue and radiation pneumonitis. Although this is in vitro study but death of melanoma cells is significant and no toxic effects on primary cells at total dose of 2 Gy in four cycles.

In conclusion, our study is a significant finding that supports the use of radiotherapy with chemo for melanoma when standard radiotherapy fails to kill melanoma cells due to radio-resistance. Although future studies using in vivo models will be required to prove this concept for clinical settings, this study indicates the effectiveness of paclitaxel when combined with a high dose rate of radiation (2400MU/min) and a low total dose (0.5Gy) in melanoma therapy.

\section{Acknowledgements:}

We thank The John Theurer Cancer Center and Radiology and Oncology Department of the Hackensack University Medical Center. We are thankful to the Lisa B. Fishman Foundation and the John Theurer Cancer Center of the Hackensack Meridian Health network for continuous support during preparation of this manuscript. We thank Esra Uckun Kiran and Shermineh Bradford for participating in Radiobiology experiments.

\section{Conflict of Interest Statement:}

No potential conflicts of interest were disclosed by the authors. 


\section{References:}

1 A. Hong, G. Fogarty and M.A. Izard, The role of radiation therapy in the management of metastatic melanoma in the brain. International journal of surgical oncology 2012, 294735 (2012)

2 D.M. Palathinkal, T.R. Sharma, H.B. Koon and J.S. Bordeaux, Current systemic therapies for melanoma. Dermatologic surgery : official publication for American Society for Dermatologic Surgery [et al.] 40, 948963 (2014)

3 S.C. Barranco, M.M. Romsdahl and R.M. Humphrey, The radiation response of human malignant melanoma cells grown in vitro.Cancer research 31, 830-833 (1971) Web of Science

4 S.M. Bentzen, J. Overgaard, H.D. Thames, M. Overgaard, P. Vejby Hansen, H. von der Maase and J. Meder, Clinical radiobiology of malignant melanoma. Radiotherapy and oncology : journal of the European Society for Therapeutic Radiology and Oncology 16, 169-182 (1989) Web of Science

5 S. Stieb, S. Lang, C. Linsenmeier, S. Graydon and O. Riesterer, Safety of high-dose-rate stereotactic body radiotherapy. Radiation oncology 10, 27 (2015)

6 P. Patonay, A. Naszaly, A. Mayer, K. Pocza and L. Kovacs, Magyar onkologia 48, 303-308 (2004) doi: HUON.2004.48.4.0303

7 S. Kumar, H. Mahdi, C. Bryant, J.P. Shah, G. Garg and A. Munkarah, Clinical trials and progress with paclitaxel in ovarian cancer. International journal of women's health 2, 411-427 (2010)

8 A. Jain, B. Dubashi, K.S. Reddy and P. Jain, Weekly paclitaxel in ovarian cancer-the latest success story. Current oncology 18, 16-17 (2011)

$9 \mathrm{~N}$. Katsumata, Dose-dense therapy is of benefit in primary treatment of ovarian cancer? In favor. Annals of oncology : official journal of the European Society for Medical Oncology 22 Suppl 8, viii29viii32 (2011)

10 D.K. Armstrong, B. Bundy, L. Wenzel, H.Q. Huang, R. Baergen, S. Lele, L.J. Copeland, J.L. Walker, R.A. Burger and G. Intraperitoneal cisplatin and paclitaxel in ovarian cancer. Gynecologic Oncology, The New England journal of medicine 354, 34-43 (2006)

11 Z.N. Wee, S.M. Yatim, V.K. Kohlbauer, M. Feng, J.Y. Goh, Y. Bao, P.L. Lee, S. Zhang, P.P. Wang, E. Lim, W.L. Tam, Y. Cai, H.J. Ditzel, D.S. Hoon, E.Y. Tan and Q. Yu, IRAK1 is a therapeutic target that drives breast cancer metastasis and resistance to paclitaxel. Nature communications 6, 8746 (2015)

12 A.L. Risinger, N.F. Dybdal-Hargreaves and S.L. Mooberry, Breast cancer cell lines exhibit differential sensitivities to microtubule-targeting drugs independent of doubling time. Anticancer research $35,5845-$ 5850 (2015)

13 M.E. Herce, N. Kalanga, E.B. Wroe, J.W. Keck, F. Chingoli, L. Tengatenga, S. Gopal, A. Phiri, B. Mailosi, J. Bazile, J.A. Beste, S.N. Elmore, J.T. Crocker and J. Rigodon, Excellent clinical outcomes and retention in care for adults with HIV-associated Kaposi sarcoma treated with systemic chemotherapy and integrated antiretroviral therapy in rural Malawi. Journal of the International AIDS Society 18, 19929 (2015) 
14 S. Reddy-Holdcraft, P.S. Mehta and A.K. Agrawal, Paclitaxel for relapsed or recurrent HIV-associated pediatric Kaposi's sarcoma. Aids 28, 800-802 (2014)

15 K. Raimundo, J. Biskupiak, M. Goodman, S. Silverstein and C. Asche, Cost effectiveness of liposomal doxorubicin vs. paclitaxel for the treatment of advanced AIDS-Kaposi's sarcoma. Journal of medical economics 16, 606-613 (2013)

16 T. Tsuji, Y.H. Kim, H. Ozasa, Y. Sakamori, H. Nagai, H. Ajimizu, Y. Yagi, A. Furukawa, H. Haga and M. Mishima, Successful treatment with carboplatin and nanoparticle albumin-bound paclitaxel in a patient with pulmonary spindle cell carcinoma. Respiratory medicine case reports 15, 48-50 (2015)

17 X.C. Peng, X.X. Chen, Y.U. Zhang, H.J. Wang and Y. Feng, A novel inhibitor of Rho GDP-dissociation inhibitor alpha improves the therapeutic efficacy of paclitaxel in Lewis lung carcinoma. Biomedical reports 3, 473-477 (2015)

18 W. Zhang, C. Li, C. Shen, Y. Liu, X. Zhao, D. Zou, Z. Gao and C. Yue, Prodrug-based nano-drug delivery system for co-encapsulate paclitaxel and carboplatin for lung cancer treatment. Drug delivery, 1-6 (2015)

19 L. Huang, S. Chen, W. Yang, B. Xu, T. Huang, H. Yang, H. Zheng, Y. Wang, E. Song, J. Zhang, S. Cui, D. Pang, L. Tang, Y. Lei, C. Geng and Z. Shao, Efficacy and safety analysis of trastuzumab and paclitaxel based regimen plus carboplatin or epirubicin as neoadjuvant therapy for clinical stage II-III, HER2positive breast cancer patients: a phase 2, open-label, multicenter, randomized trial. Oncotarget 6, 18683-18692 (2015)

20 K. Inoue, K. Kuroi, S. Shimizu, Y. Rai, K. Aogi, N. Masuda, T. Nakayama, H. Iwata, Y. Nishimura, A. Armour and Y. Sasaki, Safety, pharmacokinetics and efficacy findings in an open-label, single-arm study of weekly paclitaxel plus lapatinib as first-line therapy for Japanese women with HER2-positive metastatic breast cancer. International journal of clinical oncology 20, 1102-1109 (2015)

21 G. Kutomi, T. Ohmura, F. Satomi, H. Maeda, H. Shima, H. Kameshima, M. Okazaki, H. Masuoka, K. Sasaki and K. Hirata, A phase I study of combination therapy with nanoparticle albumin-bound paclitaxel and cyclophosphamide in patients with metastatic or recurrent breast cancer. International journal of clinical oncology 20, 474-479 (2015)

22 J. Salvador, L. Manso, J. de la Haba, A. Jaen, E. Ciruelos, M.C. de Villena, M. Gil, A. Murias, A. Galan, C. Jara, J. Bayo, J.M. Baena, J. Casal, J.R. Mel, I. Blancas and P. Sanchez Rvira, Final results of a phase II study of paclitaxel, bevacizumab, and gemcitabine as first-line therapy for patients with HER2-negative metastatic breast cancer. Clinical \& translational oncology : official publication of the Federation of Spanish Oncology Societies and of the National Cancer Institute of Mexico 17, 160-166 (2015) doi: $10.1007 / \mathrm{s} 12094-014-1210-x$

23 G.A. Croghan, V.J. Suman, W.J. Maples, M. Albertini, G. Linette, L. Flaherty, J. Eckardt, C. Ma, S.N. Markovic and C. Erlichman, A study of paclitaxel, carboplatin, and bortezomib in the treatment of metastatic malignant melanoma: a phase 2 consortium study. Cancer 116, 3463-3468 (2010) 
24 S. Bhatia, J. Moon, K.A. Margolin, J.S. Weber, C.D. Lao, M. Othus, A.M. Aparicio, A. Ribas and V.K. Sondak, Phase II trial of sorafenib in combination with carboplatin and paclitaxel in patients with metastatic uveal melanoma: SWOG S0512. PloS one 7, e48787 (2012)

25 M. Moschetta, F. Pretto, A. Berndt, K. Galler, P. Richter, A. Bassi, P. Oliva, E. Micotti, G. Valbusa, K. Schwager, M. Kaspar, E. Trachsel, H. Kosmehl, M.R. Bani, D. Neri and R. Giavazzi, Paclitaxel enhances therapeutic efficacy of the F8-IL2 immunocytokine to EDA-fibronectin-positive metastatic human melanoma xenografts. Cancer research 72, 1814-1824 (2012)

26 L.E. Spitler, P. Boasberg, S. O'Day, O. Hamid, S. Cruickshank, S. Mesko and R.W. Weber, Phase II study of nab-paclitaxel and bevacizumab as first-line therapy for patients with unresectable stage III and IV melanoma. American journal of clinical oncology 38, 61-67 (2015)

27 L. Tu, L. Sun, Y. Xu, Y. Wang, L. Zhou, Y. Liu, J. Zhu, F. Peng, Y. Wei and Y. Gong, Paclitaxel and cisplatin combined with intensity-modulated radiotherapy for upper esophageal carcinoma. Radiation oncology 8,75 (2013)

28 S. Sarojini, A. Pecora, N. Milinovikj, J. Barbiere, S. Gupta, Z.M. Hussain, M. Tuna, J. Jiang, L. Adrianzen, J. Jun, L. Catello, D. Sanchez, N. Agarwal, S. Jeong, Y. Jin, Y. Remache, A. Goy, A. Ndlovu, A. Ingenito and K.S. Suh, A combination of high dose rate (10X FFF/2400 MU/min/10 MV X-rays) and total low dose (0.5 Gy) induces a higher rate of apoptosis in melanoma cells in vitro and superior preservation of normal melanocytes. Melanoma research 25, 376-389 (2015)

29 K.S. Suh, M. Mutoh, T. Mutoh, L. Li, A. Ryscavage, J.M. Crutchley, R.A. Dumont, C. Cheng and S.H. Yuspa, CLIC4 mediates and is required for Ca2+-induced keratinocyte differentiation. Journal of cell science 120, 2631-2640 (2007)

30 K.J. Livak and T.D. Schmittgen, Analysis of relative gene expression data using real-time quantitative PCR and the 2(-Delta Delta C(T)) Method. Methods 25, 402-408 (2001) Web of Science

31 R. Li, T. Moudgil, H.J. Ross and H.M. Hu, Apoptosis of non-small-cell lung cancer cell lines after paclitaxel treatment involves the BH3-only proapoptotic protein Bim. Cell Death Differ 12, 292-303 (2005)

32 N.A. Franken, H.M. Rodermond, J. Stap, J. Haveman and C. van Bree, Clonogenic assay of cells in vitro. Nature protocols 1, 2315-2319 (2006) Web of Science

33 M.S. Poruchynsky, E. Komlodi-Pasztor, S. Trostel, J. Wilkerson, M. Regairaz, Y. Pommier, X. Zhang, T. Kumar Maity, R. Robey, M. Burotto, D. Sackett, U. Guha and A.T. Fojo, Microtubule-targeting agents augment the toxicity of DNA-damaging agents by disrupting intracellular trafficking of DNA repair proteins. Proceedings of the National Academy of Sciences of the United States of America 112, 15711576 (2015)

34 C.E. Redon, J.S. Dickey, W.M. Bonner and O.A. Sedelnikova, $\mathrm{y}-\mathrm{H} 2 \mathrm{AX}$ as a biomarker of DNA damage induced by ionizing radiation in human peripheral blood lymphocytes and artificial skin. Advances in space research : the official journal of the Committee on Space Research 43, 1171-1178 (2009) 
35 J.P. Banath, S.H. Macphail and P.L. Olive, Radiation sensitivity, H2AX phosphorylation, and kinetics of repair of DNA strand breaks in irradiated cervical cancer cell lines. Cancer research 64, 7144-7149 (2004)

36 M. Podhorecka, A. Skladanowski and P. Bozko, H2AX Phosphorylation: Its Role in DNA Damage Response and Cancer Therapy. Journal of nucleic acids 2010, (2010)

37 A. Ivashkevich, C.E. Redon, A.J. Nakamura, R.F. Martin and O.A. Martin, Use of the $\mathrm{Y}$-H2AX assay to monitor DNA damage and repair in translational cancer research. Cancer letters 327, 123-133 (2012)

38 N. Taneja, M. Davis, J.S. Choy, M.A. Beckett, R. Singh, S.J. Kron and R.R. Weichselbaum, Histone H2AX phosphorylation as a predictor of radiosensitivity and target for radiotherapy. The Journal of biological chemistry 279, 2273-2280 (2004)

39 R. Xie, Y. Li, P. Tang and Q. Yuan, Rational design, synthesis and preliminary antitumor activity evaluation of a chlorambucil derivative with potent DNA/HDAC dual-targeting inhibitory activity. Bioorganic \& medicinal chemistry letters 27, 4415-4420 (2017)

40 G.L. Gravina, A. Mancini, A. Colapietro, F. Vitale, A. Vetuschi, S. Pompili, G. Rossi, F. Marampon, P.J. Richardson, L. Patient, L. Patient, S. Burbidge and C. Festuccia, The novel CXCR4 antagonist, PRX177561, reduces tumor cell proliferation and accelerates cancer stem cell differentiation in glioblastoma preclinical models. Tumour biology : the journal of the International Society for Oncodevelopmental Biology and Medicine 39, 1010428317695528 (2017)

41 J.S. Lou, L. Yan, C.W. Bi, G.K. Chan, Q.Y. Wu, Y.L. Liu, Y. Huang, P. Yao, C.Y. Du, T.T. Dong and K.W. Tsim, Yu Ping Feng San reverses cisplatin-induced multi-drug resistance in lung cancer cells via regulating drug transporters and p62/TRAF6 signalling. Scientific reports 6, 31926 (2016)

42 T. Yamamori, H. Yasui, M. Yamazumi, Y. Wada, Y. Nakamura, H. Nakamura and O. Inanami, lonizing radiation induces mitochondrial reactive oxygen species production accompanied by upregulation of mitochondrial electron transport chain function and mitochondrial content under control of the cell cycle checkpoint. Free radical biology \& medicine 53, 260-270 (2012)

43 S.K. Sim, Y.C. Tan, J.H. Tee, A.A. Yusoff and J.M. Abdullah, Paclitaxel inhibits expression of neuronal nitric oxide synthase and prevents mitochondrial dysfunction in spinal ventral horn in rats After C7 spinal root avulsion. Turkish neurosurgery 25, 617-624 (2015) $44 \quad$ H.L. Tang, H.M. Tang, K.H. Mak, S. Hu, S.S. Wang, K.M. Wong, C.S. Wong, H.Y. Wu, H.T. Law, K. Liu, C.C. Talbot, Jr., W.K. Lau, D.J. Montell and M.C. Fung, Cell survival, DNA damage, and oncogenic transformation after a transient and reversible apoptotic response. Molecular biology of the cell 23, 2240-2252 (2012)

45 S.M. de La Monte and J.R. Wands, Mitochondrial dna damage and impaired mitochondrial function contribute to apoptosis of insulin-stimulated ethanol-exposed neuronal cells. Alcoholism, clinical and experimental research 25, 898-906 (2001)

46 S.A. Susin, N. Zamzami and G. Kroemer, Mitochondria as regulators of apoptosis: doubt no more. Biochimica et biophysica acta 1366, 151-165 (1998)

$47 \mathrm{H}$. Braselmann, A. Michna, J. Hess and K. Unger, CFAssay: statistical analysis of the colony formation assay. Radiation oncology 10, 223 (2015) 
48 R. Jamal, R. Lapointe, E. Cocolakis, P. Thebault, S. Kazemi, J.E. Friedmann, J. Dionne, J.F. Cailhier, K. Belanger, J.P. Ayoub, H. Le, C. Lambert, J. El-Hajjar, L.C. van Kempen, A. Spatz and W.H. Miller, Jr., Peripheral and local predictive immune signatures identified in a phase II trial of ipilimumab with carboplatin/paclitaxel in unresectable stage III or stage IV melanoma. Journal for immunotherapy of cancer 5, 83 (2017) 
Figure Legends:

\section{Figure 1.}

Melanoma cell line (WC00046), normal skin cells (HEM, HEK, and HDF) were irradiated (Rad x1 to x4) with and without paclitaxel.

(A). Melanoma cell lines showed significant reduction in cell survival $\%$ after the third radiation in paclitaxel treated cells. Normal cells survival was $>80 \%$ even after treating with paclitaxel. The statistical significance between the two dose rates for WC00046 with paclitaxel $(*)$ is $p<0.002$, for $\operatorname{Rad} \times 2$ is $\left.\mathrm{p}<0.006{ }^{(* *}\right), \operatorname{Rad} x 3$ is $\mathrm{p}<0.001(* * *)$, and $\operatorname{Rad} x 4 \mathrm{p}<0.002(* * * *)$.

(B). Live imaging of melanoma or normal cells irradiated cells.

Cells in T25 culture flasks using the IDEA camera, Spot 5 by phase contrast microscopy after 4 radiations (Rad x4). Control cells from the melanoma cell line, HEM, HEK and HDF are given in inset. Each cell line radiated under $400 \mathrm{MU}$ and $2400 \mathrm{MU}$ with and without paclitaxel is visualized in this image.

Figure 2.

(A). DNA damage (fold) of irradiated cells with and without co-administration of paclitaxel for both dose rates $400 \mathrm{MU} / \mathrm{min}$ and $2400 \mathrm{MU} / \mathrm{min}$ are shown after the fourth radiation ( $\operatorname{Rad} \mathrm{x} 4$ ). Data represent the average of four independent experiments with error bars. The statistical difference between $400 \mathrm{MU} / \mathrm{min}$ and $2400 \mathrm{MU} / \mathrm{min}$ with paclitaxel is shown $(* *) p<0.004$.

(B). Mutational status of cell cycle genes CCND1, CCND2, Radioprotection gene SOD2, AIF, PTEN, and BBC3 were quantified via qRT-PCR analysis.

Figure 3. Cell proliferation was quantified by MTT assay.

(A). Cell proliferation was quantified by MTT assay for irradiated cells from (A) and standard error bars and statistical $p$ values are shown as $(*)$. For the melanoma cell line, the statistical significance between $400 \mathrm{MU} / \mathrm{min}$ and $2400 \mathrm{MU} / \mathrm{min}$ with $\mathrm{P}\left({ }^{*}\right)$ is $\mathrm{p}<0.005$, for $\operatorname{Rad} x 2$ is $p<0.006\left({ }^{* *}\right), \operatorname{Rad} x 3$ is $p<0.002(* * *)$, and $\operatorname{Rad} x 4 \mathrm{p}<0.005(* * * *)$. (B) The mutational status of the mitochondrial respiration gene UCRC was analyzed using $\mathrm{qRT}-\mathrm{PCR}$, and the average fold changes against non-radiated control cells are shown.

Figure 4. Effect of radiations and paclitaxel on the expression of DNA repair and ant-apoptosis genes.

Western Blot analyses of Bcl-2 (A), Caspase3 (B), PARP1 (C), and Doxorubicin (Dx) treated cell lysates were used as positive controls $(+C)$. The samples used were from a Rad $x 4$ experimental setting with $(+P A C)$ or without (-PAC) paclitaxel and with (T) or without $(U)$ radiation treatment. Subsequently, q RTPCR analysis of the same Bcl-2, PARP1, and Caspase 3 were also carried out, and fold expressions were shown in graphs. 
Figure 5. Effect of radiations and paclitaxel on mitochondrial respiration using Mitotracker Redfluorescent dye.

(A). The average fluorescent intensity from five random fields for each experimental setting was used to calculate the relative fluorescent intensity using Image J, and was normalized against the average intensity of the non-radiated control (solid black) for each cell type. The fold changes for dose rates $400 \mathrm{MU} / \mathrm{min}$ (solid white) and $2400 \mathrm{MU} / \mathrm{min}$ (solid gray) are shown with standard error bars. Paclitaxel control $(P)$ data are represented with black dots over white; $400 \mathrm{MU} / \mathrm{min}+\mathrm{P}$ are shown in white over black, and $2400 \mathrm{MU} / \mathrm{min}$ is in horizontal diamond bars. The statistical significance between the two dose rates for WC00046 with paclitaxel $\left({ }^{*}\right)$ is $\left.p<0.005\right)$.

(B). The melanoma cell line, HEM, HDF, and HEK cells were radiated with and without paclitaxel four times ( $\operatorname{Rad} \times 1, \operatorname{Rad} \times 2, \operatorname{Rad} \times 3$, and $\operatorname{Rad} \times 4)$. The image represents $\operatorname{Rad} \times 4$ data. Cells were collected and seeded and stained the following day using Mitotracker Red-fluorescent dye to detect mitochondrial respiration, and florescence microscopy was used for imaging at 20X magnification with scale bars. Nonradiated control cells (inset) are shown for individual radiation settings for each cell type.

Figure 6. Colony formation assays after each radiation and paclitaxel experiment.

(A). Cells were counted, serially diluted, and plated on culture grade petri dishes. After 2-3 weeks colonies were stained and counted, and the survival percent (\%) was calculated. The statistical significance between the two dose rates for WC00046 with paclitaxel $(*)$ is $p<0.001$, for $\operatorname{Rad} \times 2$ is $\mathrm{p}<0.004(* *), \operatorname{Rad} x 3$ is $\mathrm{p}<0.005(* * *)$, and $\operatorname{Rad} x 4 \mathrm{p}<0.002(* * * *)$.

(B). Images of colonies from the colony assay plates after staining with hemotoxylin.

Melanoma cell lines were radiated with and without paclitaxel. The image represents Rad x4 data. 


\section{SUPPLEMENTAL FIGURE AND TABLES:}

\section{Supplementary Figure 1.}

Radiation dose administration to melanoma or normal cells.

Cell groups were divided into one radiation ( $\operatorname{Rad} x 1$, on day 1$)$, second radiation ( $\operatorname{Rad} x 2$; day 2$)$, third radiation ( $\operatorname{Rad} \times 3$; day 3 ), and fourth radiation ( $\operatorname{Rad} \times 4$; day 4$)$.

\section{Supplementary Table 1.}

Cell groups for Paclitaxel or Paclitaxel with irradiation treatment.

\section{Supplementary Table 2.}

Primer sequences used in this study. 
(A)

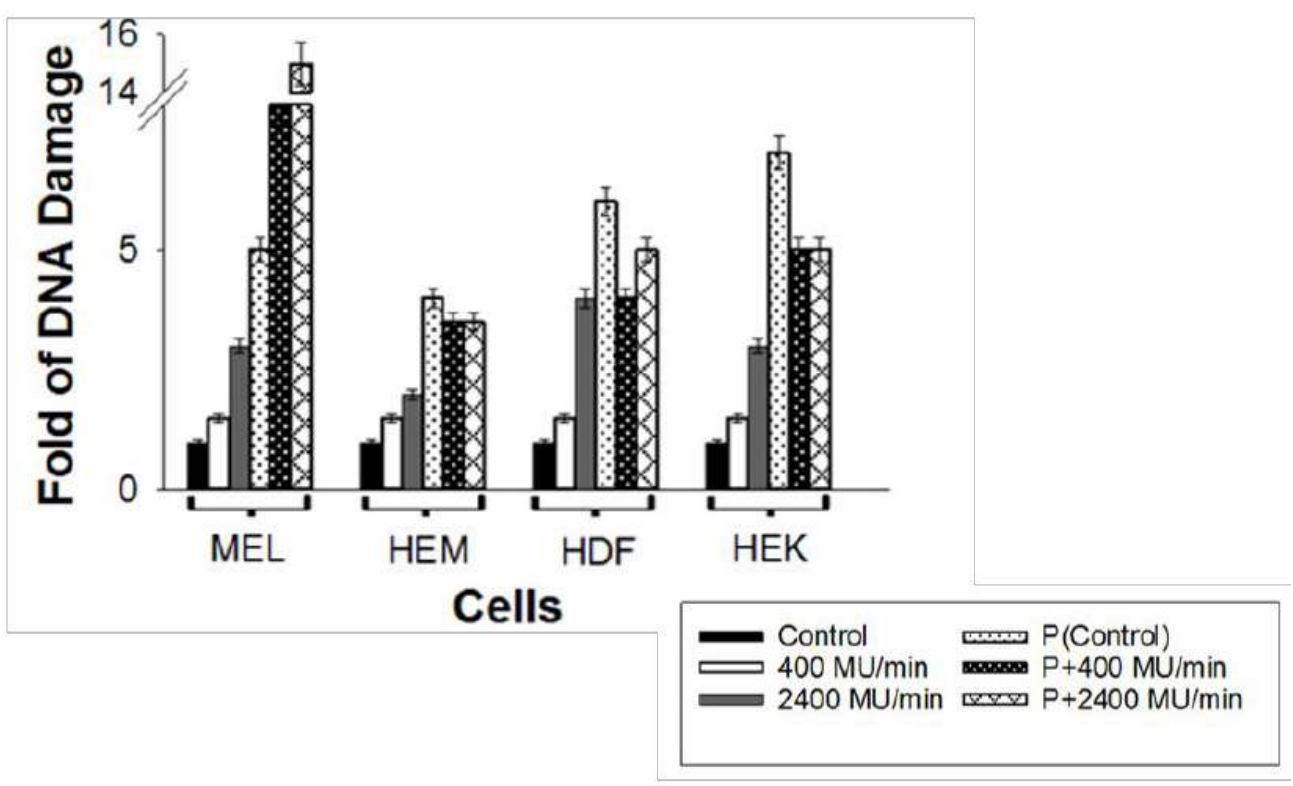

(B)
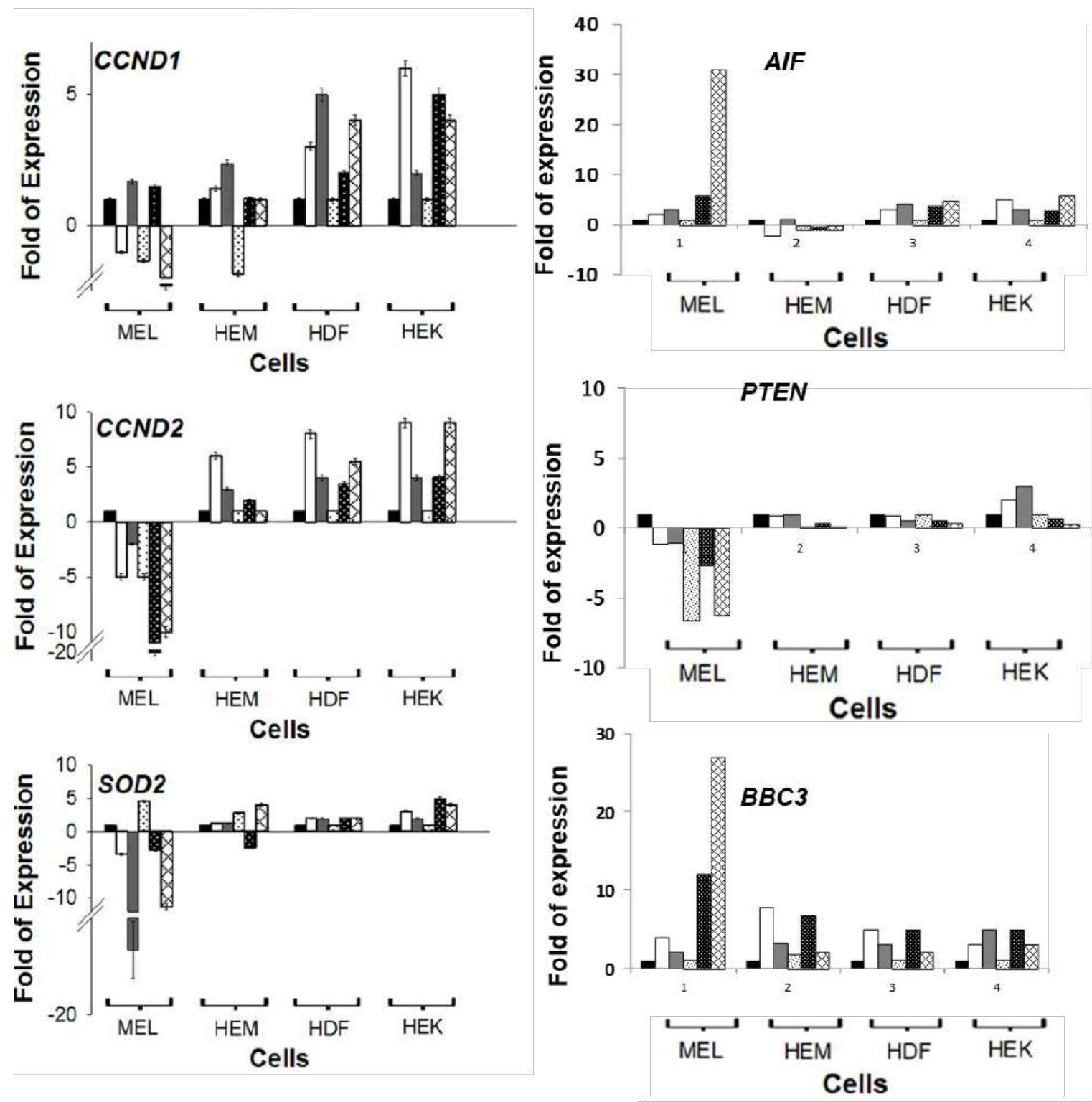
Figure 3

(a)

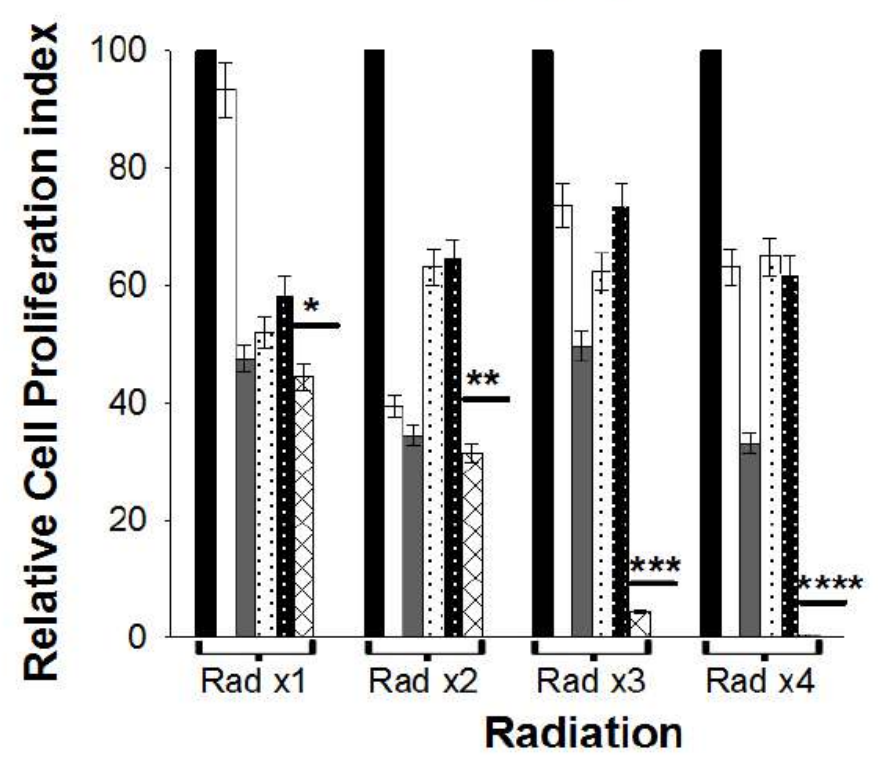

HDF

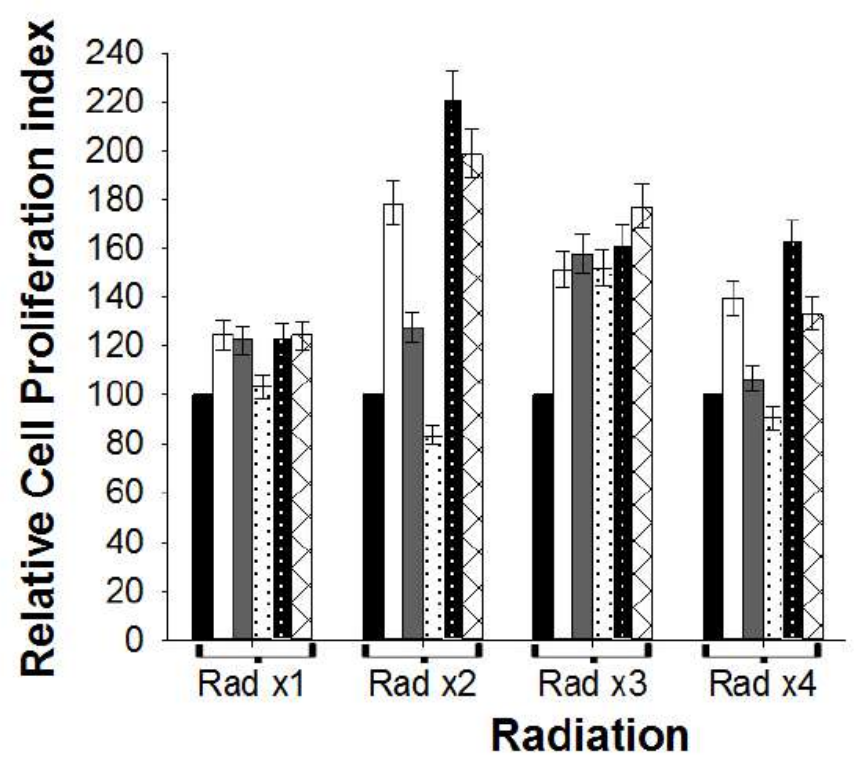

(b)

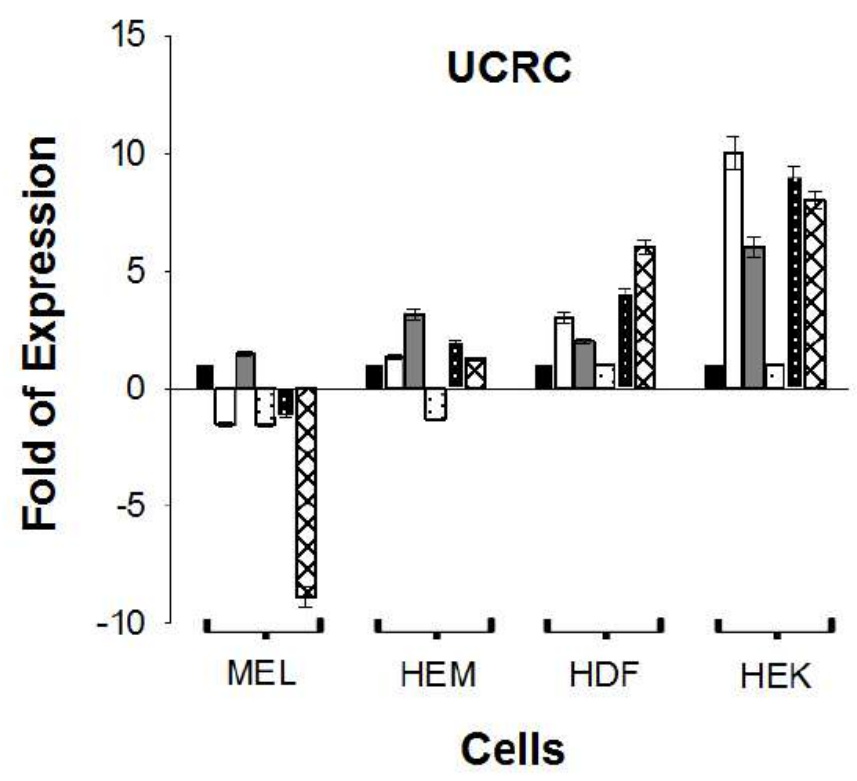

HEM

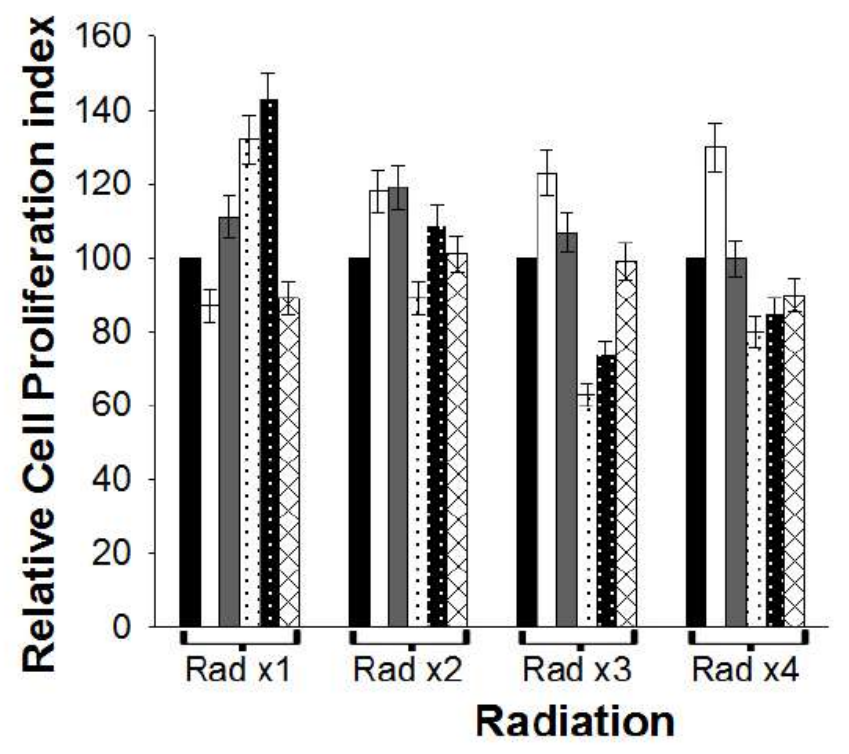

HEK

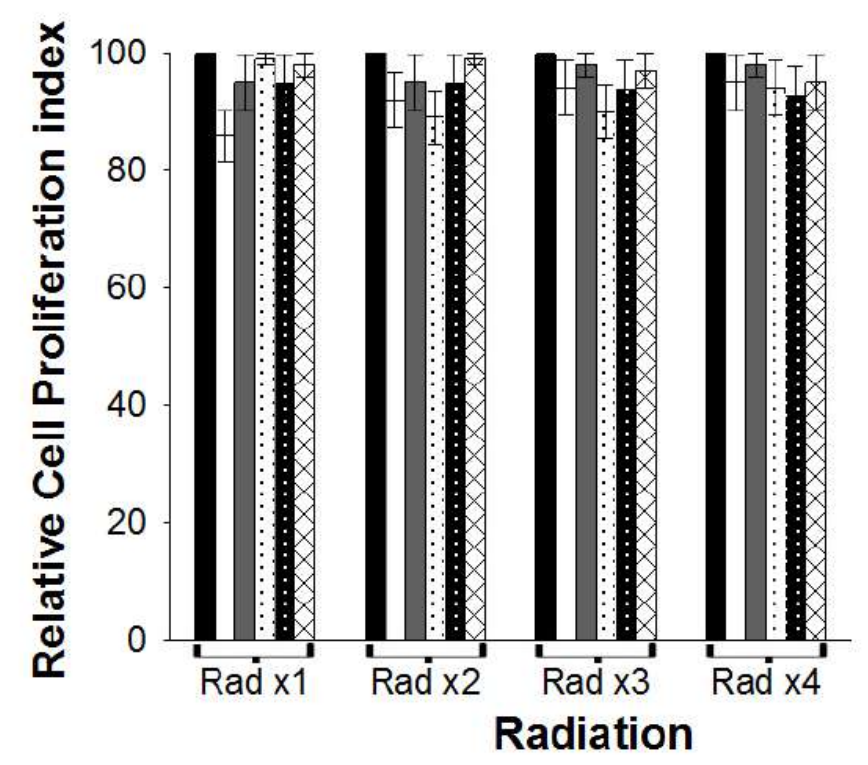


Figure 4

(a)

HEM HDF HEK MEL +C UT $\overline{U T} \frac{\text { T }}{U T}$ +Dx

Bcl2

Actin

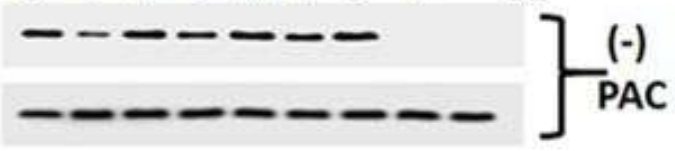

HEM HDF HEK MEL +C UT UT UT UT +DX

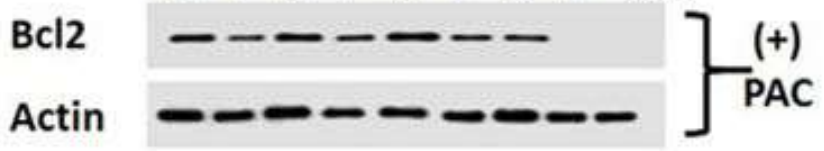

(b)

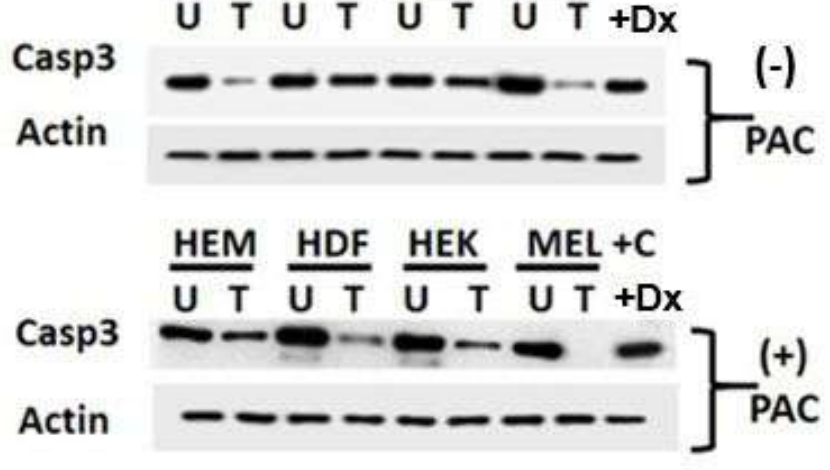

HEM HDF HEK MEL +C $\overline{U T} \overline{U T} \overline{U T} \overline{U T}+D x$

(c)

HEM HDF HEK MEL +C U T U T U T U T +Dx

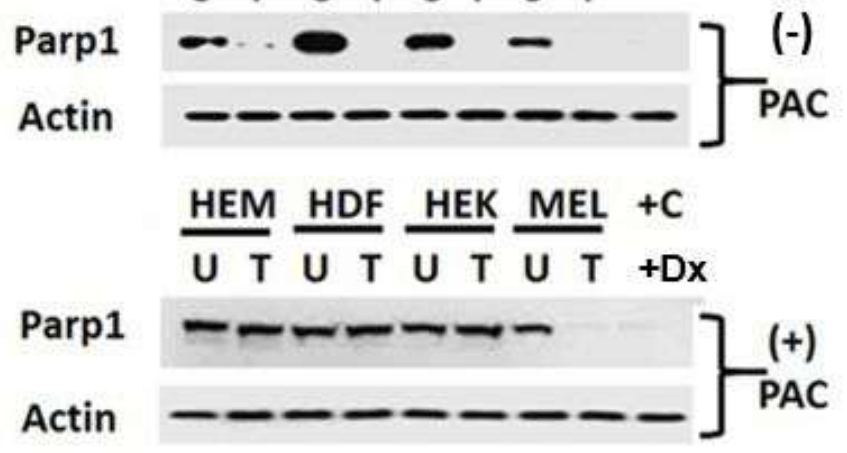

PAC - Paclitaxel $\left.\begin{array}{l}\text { U- Untreated } \\ \text { T-Treated }\end{array}\right]$ Radiations

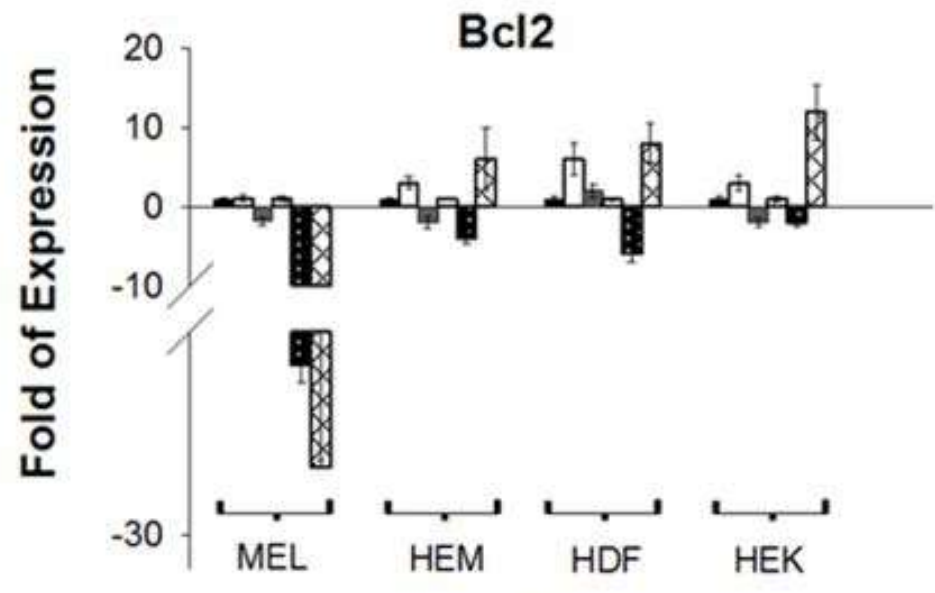

Cells

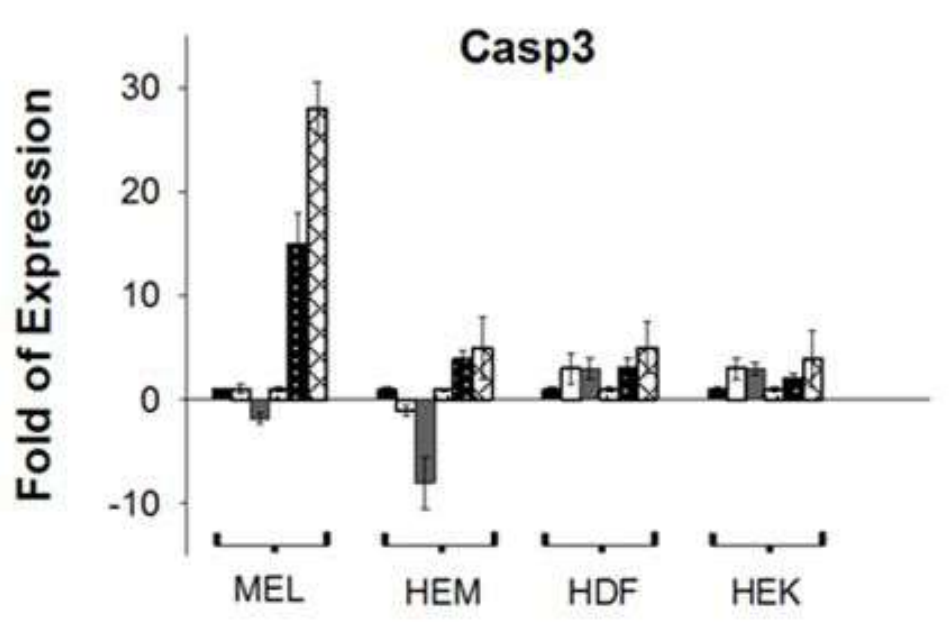

Cells

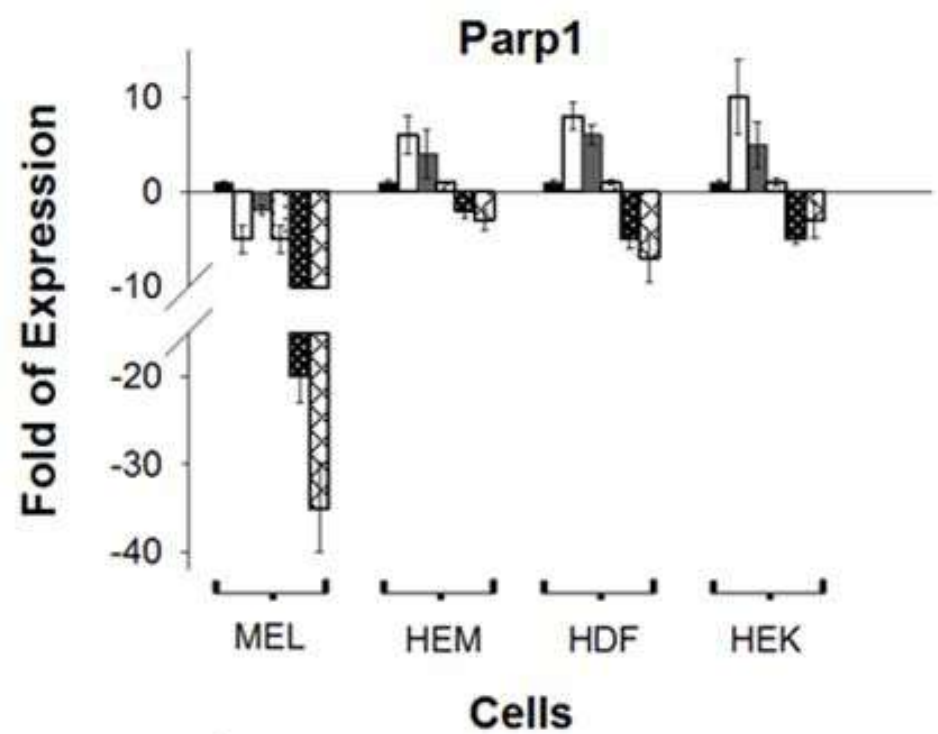

Cells 
Eibgure

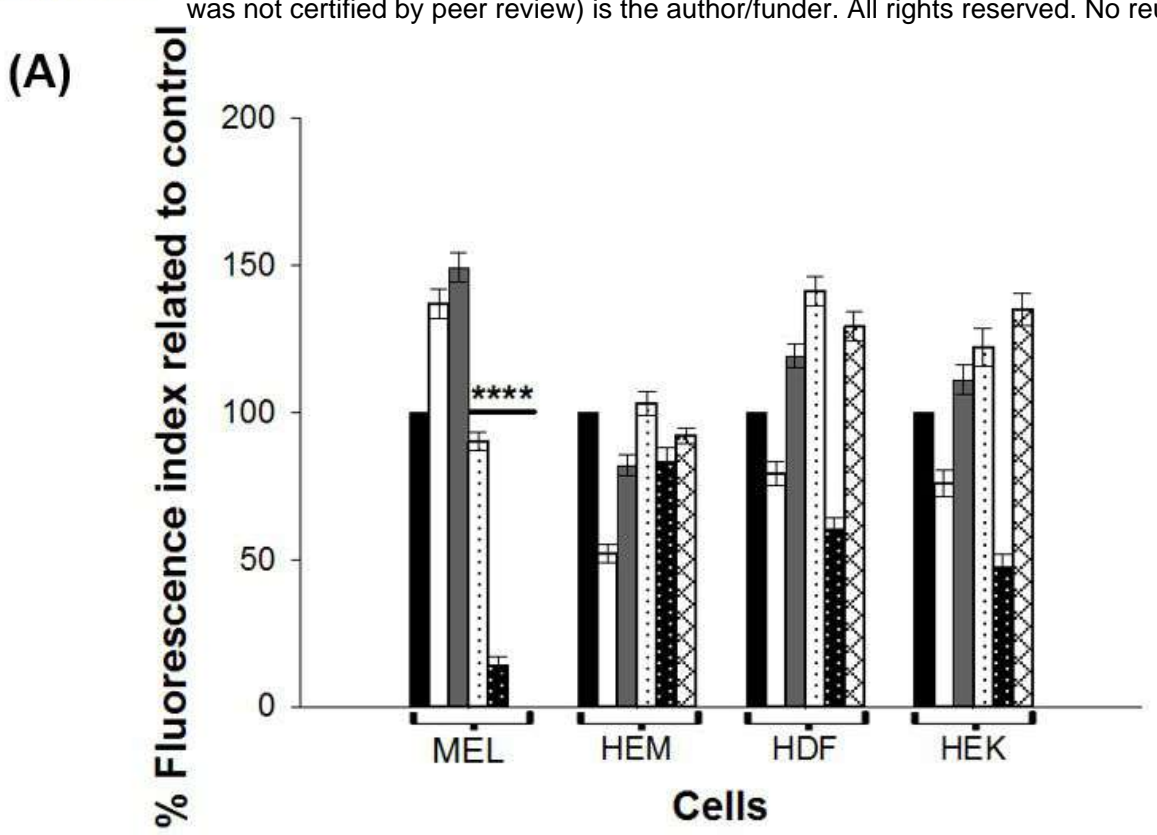

(B)

Radiations $\times 4$

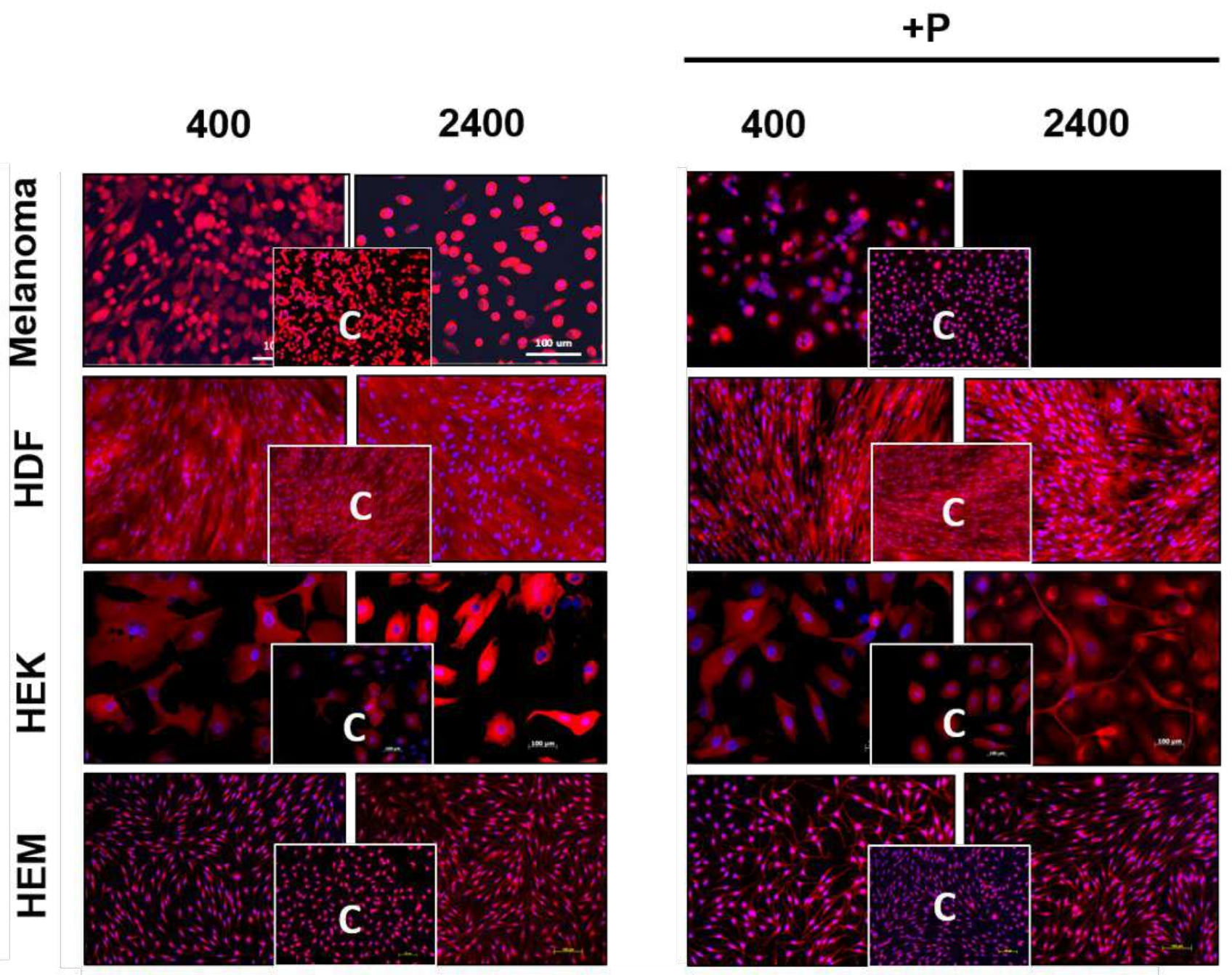


